\title{
Pemetaan Risiko Tsunami terhadap Bangunan secara Kuantitatif
}

\section{Totok Wahyu Wibowo, Djati Mardiatno, dan Sunarto}

Faculty of Geography, Universitas Gadjah Mada, Yogyakarta, Indonesia

Email Koresponden: totok.wahyu@ugm.ac.id

Diterima : April 2017 ; Direvisi : Juli 2017; Dipubikasikan: September 2017

(c) 2017 Fakultas Geografi UGM dan Ikatan Geograf Indonesia.

\begin{abstract}
Abstrak Tsunami merupakan bencana alam yang sebagian besar kejadiannya dipicu oleh gempabumi dasar laut. Dampakkerugian tsunami terhadap lingkungan pesisir antara lain rusaknya properti, struktur bangunan, infrastruktur dan dapat mengakibatkan gangguan ekonomi. Bencana tsunami memiliki keunikan dibandingkan bencana lainnya, karena memiliki kemungkinan sangat kecil tetapi dengan ancaman yang tinggi. Paradigma Pengurangan Risiko Bencana (PRB) yang berkembang dalam beberapa tahun terakhir yang menekankan bahwa risiko merupakan hal utama dalam penentuan strategi terhadap bencana. Kelurahan Ploso, merupakan salah satu lokasi di Kabupaten Pacitan yang berpotensi terkena bencana tsunami. Pemetaan risiko bangunan dilakukan dengan metode kuantitatif, yang mana disusun atas peta kerentanan dan peta harga bangunan. Papathoma Tsunami Vulnerability 3 (PTVA-3) diadopsi untuk pemetaan kerentanan. Data harga bangunan diperoleh dari kombinasi kerja lapangan dan analisis Sistem Informasi Geografis (SIG). Hasil pemetaan risiko menunjukkan bahwa Lingkungan Barehan memiliki risiko kerugian paling tinggi diantara semua lingkungan di Kelurahan Ploso. Hasil ini dapat dijadikan sebagai acuan untuk penentuan strategi pengurangan risiko bencana di Kelurahan Ploso.
\end{abstract}

Kata kunci : Risiko bangunan, tsunami, PTVA-3, Pacitan

Abstract Tsunami is a natural disaster whose occurrences are mostly triggered by submarine earthquakes. The impact of tsunami on coastal environment includes damages to properties, building structures, and infrastructures as well as economic disruptions. Compared to other disasters, tsunamis are deemed unique because they have a very small occurrence probability but with a very high threat. The paradigm of Disaster Risk Reduction (DRR) that has developed in the last few years stresses risk as the primary factor to determine disaster strategies. Ploso Sub-district, an area in Pacitan Regency, is potentially affected by tsunamis. The risk mapping of the buildings in this sub-district was created using a quantitative method based on maps of vulnerability and building's cost. This research used Papathoma Tsunami Vulnerability 3 (PTVA-3) for vulnerability mapping. The cost of the buildings was obtained from a combination of fieldwork and Geographic Information System (GIS). The results of risk mapping showed that the Barehan Environment had the highest risk of loss among the other environments in Ploso Sub-district. These findings, thereby, can be used as a reference for determining DRR strategy in Ploso Sub-district.

Keywords: Risk of Buildings, Tsunami, PTVA-3, Pacitan.

\section{PENDAHULUAN}

Indonesia memiliki berbagai potensi bencana alam yang dapat mengganggu kehidupan penduduknya. Secara geografis, Indonesia dikelilingi oleh beberapa lempeng tektonik yang memiliki aktivitas seismik tinggi, yang dalam hal ini turut berkontribusi pada banyaknya kejadian bencana alam (Latief et al., 2000). Gempabumi merupakan dampak primer dari adanya aktivitas seismik tersebut, diikuti dengan tsunami yang merupakan bahaya sekunder.

Berdasarkan data NGDC/WDC (2011) terdapat 205 kejadian tsunami yang menerjang wilayah Indonesia. Sejumlah 17 kejadian di antaranya memiliki ketinggian limpasan lebih dari $10 \mathrm{~m}$. Kejadian Tsunami Aceh menjadi kejadian yang paling merugikan karena banyak menimbulkan korban jiwa dan kerusakan bangunan. Hal ini menyadarkan berbagai pihak akan ancaman tsunami. Selain itu, kejadian ini bahkan menjadi pemicu komunitas ilmiah untuk meneliti bahaya tsunami di Samudra Hindia (Okal and Synolakis, 2008).
Zona subduksi adalah zona dinamis di mana umumnya merupakan lokasi episentrum gempa, yang dapat memicu tsunami. Wilayah pesisir selatan Pulau Jawa yang berhadapan langsung dengan Samudra Hindia memiliki risiko tsunami yang tinggi (Marfai et al., 2008; Widianto dan Damen, 2014). Meskipun kejadian tsunami di bagian selatan Jawa lebih sedikit daripada bagian lain di Indonesia, namun sebagai pulau terpadat di Indonesia risiko tsunami tidak dapat dikesampingkan (Mardiatno, 2013).

Bangunan menjadi unsur yang paling rentan terhadap kerusakan pada kebanyakan kasus bencana. Bangunan bukan saja bernilai ekonomis tetapi juga menjadi tempat tinggal bagi penduduk yang masih selamat dari kejadian bencana (Westen et al., 2009). Dengan demikian, diperlukan adanya suatu upaya untuk mengetahui persebaran risiko bangunan agar dilakukan langkah persiapan yang tepat dalam menghadapi bencana.

Kerusakan bangunan dari tsunami dapat digolongkan ke dalam tiga bagian, yaitu 1) kerusakan 
dari dampak gelombang datang, 2) kerusakan yang disebabkan oleh puing-puing yang terbawa oleh gelombang, dan 3) kerusakan yang disebabkan oleh gelombang balik (Ramroth, 2007). Ketiga kategori tesebut akan memiliki perlakuan yang berbeda terhadap bangunan, karena setiap bangunan memiliki struktur yang belum tentu sama.

Penilaian kerentanan bangunan terhadap tsunami merupakan langkah awal untuk penilaian risiko secara kuantiatif, karena secara teoritis risiko merupakan hasil interaksi antara bahaya dengan kerentanan (UNDP, 2004; Smith dan Petley, 2008). Kajian pemetaan risiko secara kuantitatif bermanfaat sebagai dasar pengurangan risiko bencana yang rinci. Pengurangan risiko bencana merupakan salah satu upaya dalam menghadapi bencana alam agar sedapat mungkin mengurangi kerugian yang mungkin ditimbulkan. Penelitian ini bertujuan untuk menilai risiko bangunan terhadap tsunami dengan menggunakan pendekatan kuantiatif. Hasil penelitian dapat dimanfaatkan untuk pemilihan strategi pengurangan risiko bencana.

Pacitan merupakan salah satu kabupaten yang terletak di bagian selatan pulau Jawa, sehingga menjadikannya berpotensi terkena bencana tsunami. Kejadian tsunami besar di dekat Pacitan pernah terjadi tahun 1994 di Banyuwangi (Rajegwesi). Topografi Pesisir Pacitan juga berpotensi memperbesar risiko karena berupa teluk yang datar dan adanya konsentrasi permukiman. Hasil pemodelan bahaya tsunami pada skenario gempabumi hipotetik 8,5 Mw, terdapat 16 desa/keluirahan yang berpotensi terdampak langsung (Mardiatno, 2008).

Kabupaten Pacitansecaraadministratifmerupakan bagian dari Provinsi Jawa Timur. Secara umum kondisi fisik di wilayah pesisir Pacitan berupa rangkaian pegunungan kapur selatan yang menghadap Samudera Hindia dan membujur dari Gunungkidul hingga ke Trenggalek. Secara topografis, Pacitan didominasi oleh perbukitan dengan kemiringan lereng lebih dari $15 \%$, yang menyebabkan distribusi penduduk menjadi tidak merata. Konsentrasi penduduk terjadi di daerah lowland yaitu Kecamatan Pacitan. Data sensus tahun 2010 mencatat Kecamatan Pacitan memiliki kepadatan penduduk tertinggi, yaitu sebesar 915,5 Jiwa/ $\mathrm{km}^{2}$ (BPS, 2011). Secara geomorfologis Kecamatan Pacitan merupakan bentukan dari dua macam bentuklahan, yaitu fluvial dan marin, memiliki topografi yang datar dengan ketinggian kurang dari $75 \mathrm{~m}$ (Sunarto dan Rahayu, 2006).

Penelitian dilakukan di Kelurahan Ploso (Gambar 1), yang secara administratif merupakan bagian dari Kecamatan Pacitan, Kabupaten Pacitan. Pemilihan lokasi penelitian didasarkan atas beberapa hal, yaitu a) Kelurahan Ploso memiliki jumlah penduduk paling tinggi diantara tiga desa di Teluk Pacitan, sehingga diasumsikan memiliki jumlah bangunan yang paling tinggi pula; dan b) Kelurahan Ploso dilewati oleh sungai utama, yaitu Sungai Grindulu, sehingga tingkat kerawanan terhadap tsunami semakin tinggi.

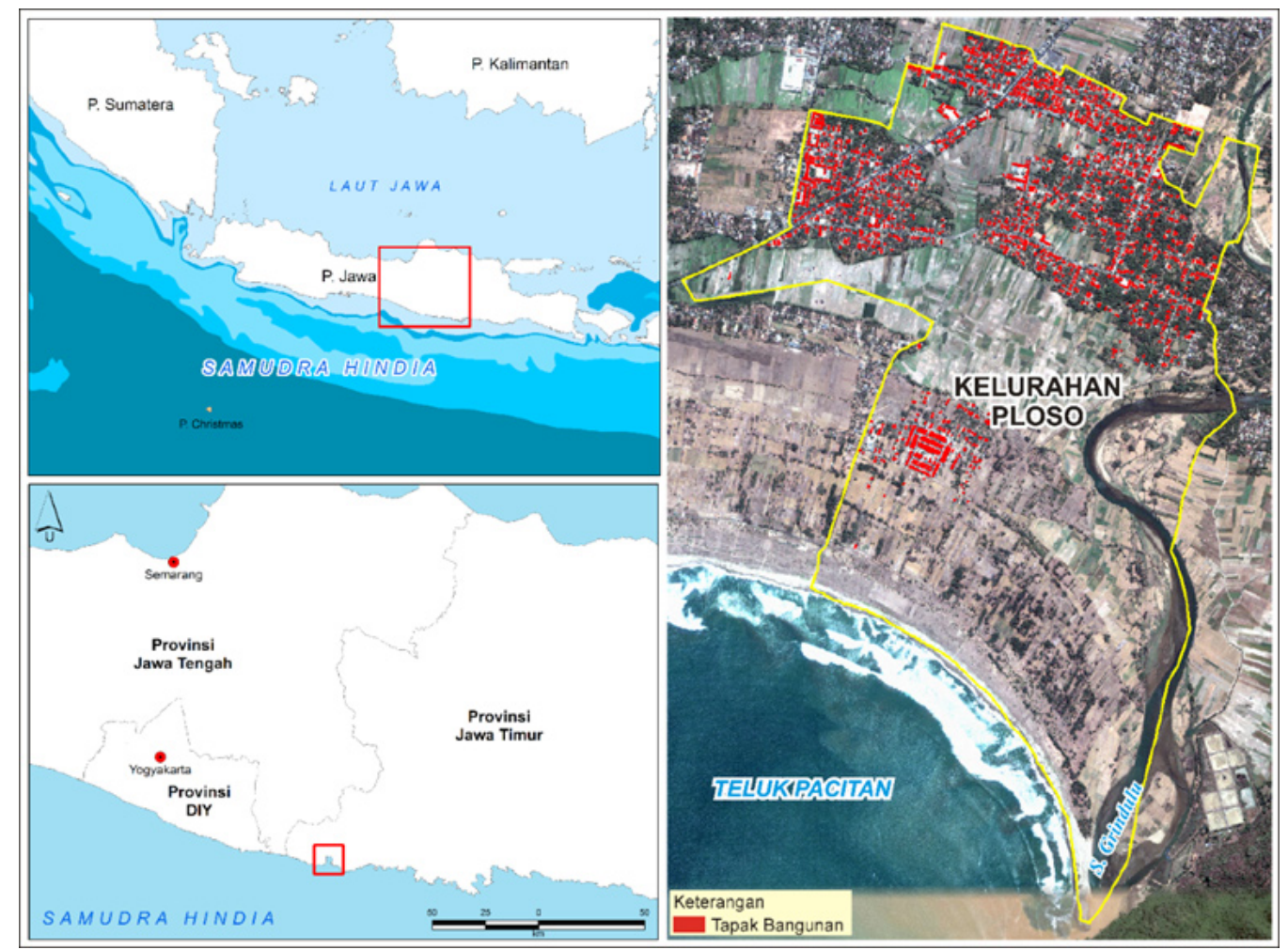

Gambar 1. Peta Lokasi Kajian Penelitian 


\section{METODE PENELITIAN}

\section{Metode Analisis Peta Bahaya Tsunami}

Peta bahaya tsunami diperoleh dari penelitian sebelumnya oleh Mardiatno (2008) yang membuat peta bahaya tsunami dalam tiga besaran magnitudo gempa hipotetik, yaitu 7,5; 8; dan 8,5 Mw (Gambar 2). Hampir semua wilayah Kelurahan Ploso terkena bahaya tsunami dengan tingkat bahaya sangat tinggi (inundasi yang lebih dari $2 \mathrm{~m}$ ) berdasarkan model gempa 8,5 Mw. Sementara itu pada magnitudo gempa hipotetik $8 \mathrm{Mw}$, tingkat bahaya tertinggi yang sampai masuk jauh ke daratan yaitu bahaya tinggi dengan inundasi $1-2 \mathrm{~m}$. Tingkat bahaya paling rendah dijumpai pada magnitudo gempa 7,5 Mw, dengan jarak inundasi ke daratan hanya mencapai $0,5 \mathrm{~m}$.

\section{Metode Analisis Peta Kerentanan Bangunan}

Struktur bangunan yang lemah (misalnya, dengan jumlah lantai sedikit, bahan bangunan yang lemah seperti kayu, pondasi dangkal, dan kondisi pemeliharaan yang buruk) lebih berpotensi mengalami kerusakan akibat bencana tsunami, meskipun hanya tegenang sebagian saja. Hal ini disebabkan oleh tekanan hidrodinamika air yang mengalir dan atau dampak dari benda hanyut seperti mobil atau perahu (Warnitchai, 2005). Di sisi lain, sebuah bangunan dengan struktur yang sangat kuat (misalnya, tiga lantai atau lebih, struktur yang terbuat dari beton bertulang, dan fondasi yang dalam) yang terkena tsunami, mungkin hanya mengalami 40-50 \% kerusakan saja, tanpa mengalami kerusakan struktural (Ramroth, 2007).
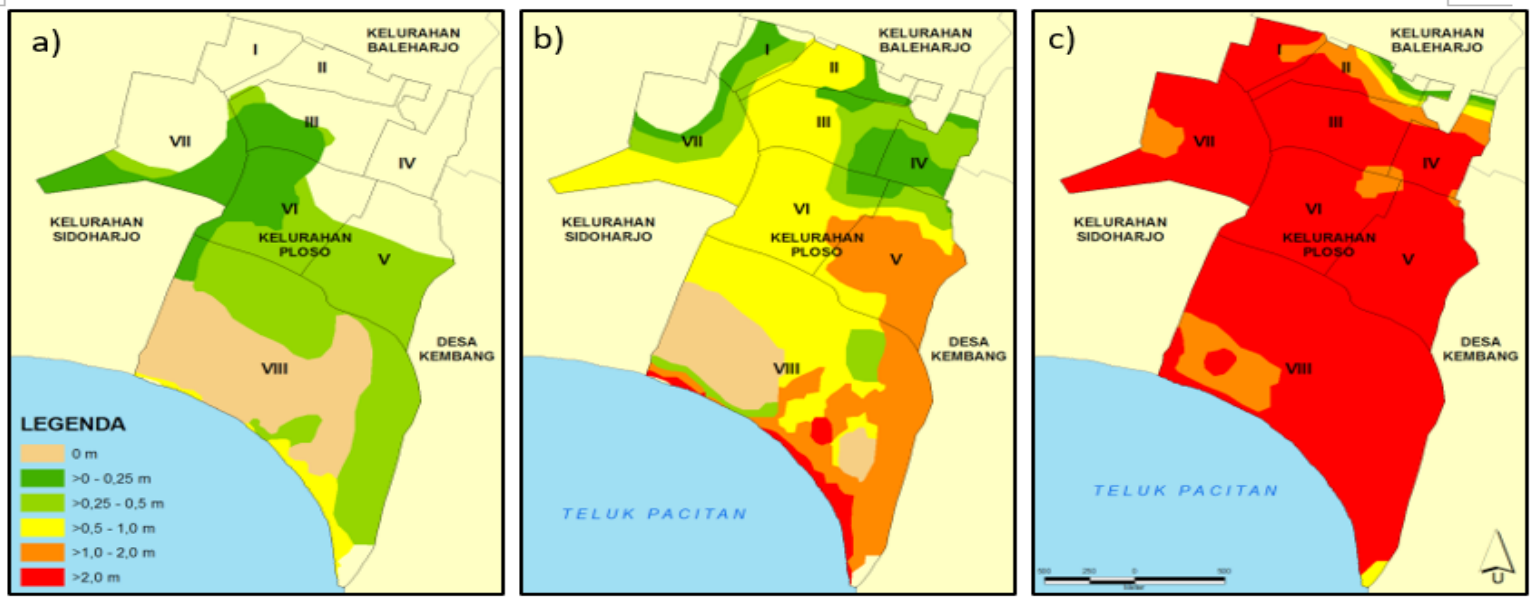

Gambar 2. Bahaya tsunami di Kelurahan Ploso dengan Magnitudo Gempa Hipotetik a) 7,5 Mw, b) 8 Mw, dan c) $8,5 \mathrm{Mw}$ (Sumber: Mardiatno, 2008)

Model Papathoma Tsunami Vulnerability Assessment 3 (PTVA-3) digunakan untuk penilaian kerentanan bangunan terhadap tsunami (Dall'Osso et al., 2009). Indeks Kerentanan Relatif (Relative Vulnerability Index/RVI) bangunan dalam model ini dihitung berdasarkan pembobotan 2 komponen sebagai berikut: a) kerentanan yang berhubungan dengan daya dukung bangunan (Structural Vulnerability/ SV); dan b) kerentanan bangunan oleh karena adanya kontak bangunan dengan air (Water contact Vulnerability/WV). Hubungan keduanya dijabarkan dalam persamaan 1 .

$$
\mathbf{R V I}=\frac{2}{3}(\mathbf{S V})+\frac{1}{3}(\mathbf{W V})
$$

Dalam model yang dijabarkan oleh Dall'Osso et al. (2009), keseluruhan variabel yang digunakan dalam penliaian RVI merupakan hasil dari analisis multi kriteria. RVI sendiri memiliki rentang nilai (terskalakan) antara 1-5, yang dikelaskan menjadi 5 kelas kerentanan (Tabel 3).
Jika dijabarkan lebih lanjut, kerentanan struktural suatu bangunan disusun oleh tiga faktor, yaitu atribut dari bangunan (Bv), derajad proteksi (Prot) yang tersedia untuk bangunan, dan kedalaman genangan air/ eksposur (Ex) pada lokasi bangunan berdiri. Hubungan ketiga faktor tersebut dijabarkan dalam persamaan 2 .

$\mathrm{SV}=(\mathrm{Bv}) \mathbf{x}($ Prot $) \mathbf{x}(\mathrm{Ex})$

\section{a. Kerentanan bangunan}

Faktor-faktor yang dinilai berkontribusi dalam kerentanan bangunan antara lain: jumlah lantai (s), material bangunan dan teknik konstruksi (m), hidrodinamisasi lantai dasar (g), fondasi (f), bentuk dan orientasi bangunan (so), keberadaan objek yang mudah bergerak (mo), dan kondisi pemeliharaan bangunan (pc). Persamaan di 3 kemudian digunakan untuk menghitung nilai kerentanan bangunan (Dall'Osso et al., 2009): 
$B v(-1,+1)=\frac{1}{423}(100 . s+80 . m+63 . g+$

$60 \cdot f+51 \cdot m o+46 . s o+23 \cdot p c)$

(3)

Penilaian masing-masing komponen kerentanan bangunan dilakukan berdasarkan pada Tabel 2 . Nilai positif mengindikasikan adanya peningkatan kerentanan bangunan sesuai dengan atributnya, sementara nilai negatif menunjukkan hal sebaliknya.

b. Derajad proteksi

Faktor-faktor yang mempengaruhi perlindungan bangunan antara lain jarak bangunan dari garis pantai $\left(\right.$ Prot $\left._{b r}\right)$, keberadaan dinding laut (Protsw), hambatan alamiah $\left(\right.$ Prot $\left._{n b}\right)$, dan keberadaan pagar di sekeliling bangunan $\left(\right.$ Prot $\left._{w}\right)$. Tabel 3 digunakan sebagai acuan untuk memberikan nilai derajad proteksi pada setiap bangunan. Faktor proteksi (Prot) dihitung dengan persamaan 4 .

$\operatorname{Prot}(0,+1)=\frac{1}{301}\left[100 \cdot\left(\right.\right.$ Prot $\left._{\text {br }}\right)+$ 73. $\left(\right.$ Prot $\left._{n \dot{b}}\right)+73 .\left(\right.$ Prot $\left._{s w}\right)+55 .\left(\right.$ Prot $\left.\left._{w}\right)\right]$

Tabel 1. Nilai Variabel Asli dan Terskalakan yang Digunakan dalam Perhitungan Nilai RVI

\begin{tabular}{|c|c|c|c|c|c|}
\hline RVI (1-5) & $1-1,8$ & $1,8-2,6$ & $2,6-3,4$ & $3,4-4,2$ & $4,2-5$ \\
\hline $\begin{array}{l}\text { Deskripsi tingkat } \\
\text { kerentanan relatif }\end{array}$ & $\begin{array}{l}\text { SANGAT } \\
\text { RENDAH }\end{array}$ & RENDAH & SEDANG & TINGGI & $\begin{array}{c}\text { SANGAT } \\
\text { TINGGI }\end{array}$ \\
\hline $\begin{array}{l}\text { SV (asli) } \\
\text { SV (terskalakan) }\end{array}$ & $\begin{array}{c}1-25 \\
1\end{array}$ & $\begin{array}{c}25-50 \\
2\end{array}$ & $\begin{array}{c}50-75 \\
3\end{array}$ & $\begin{array}{c}75-100 \\
4\end{array}$ & $\begin{array}{c}100-125 \\
5\end{array}$ \\
\hline Bv (asli) & -1 s.d $-0,6$ & $-0,6$ s.d $-0,2$ & $-0,2$ s.d 0,2 & 0,2 s.d 0,6 & 0,6 s.d 1 \\
\hline Bv (terskalakan) & 1 & 2 & 3 & 4 & 5 \\
\hline $\begin{array}{l}\text { Prot (asli) } \\
\text { Prot (terskalakan) }\end{array}$ & $\begin{array}{c}0-0,2 \\
1\end{array}$ & $\begin{array}{c}0,2-0,4 \\
2\end{array}$ & $\begin{array}{c}0,4-0,6 \\
3\end{array}$ & $\begin{array}{c}0,6-0,8 \\
4\end{array}$ & $\begin{array}{c}0,8-1 \\
5\end{array}$ \\
\hline $\begin{array}{l}\text { Ex (asli) } \\
\text { Ex (terskalakan) }\end{array}$ & $\begin{array}{c}0-1 \mathrm{~m} \\
1\end{array}$ & $\begin{array}{c}1-2 \mathrm{~m} \\
2\end{array}$ & $\begin{array}{c}2-3 \mathrm{~m} \\
3\end{array}$ & $\begin{array}{c}3-4 \mathrm{~m} \\
4\end{array}$ & $\begin{array}{c}>4 \mathrm{~m} \\
5\end{array}$ \\
\hline \multicolumn{6}{|c|}{$\mathrm{WV}=($ tingkat inundasi/jumlah total tingkatan) .... Pers. 9} \\
\hline $\begin{array}{l}\text { WV (asli) } \\
\text { WV (terskalakan) }\end{array}$ & $\begin{array}{c}0-0,2 \\
1 \\
\end{array}$ & $\begin{array}{c}0,2-0,4 \\
2 \\
\end{array}$ & $\begin{array}{c}0,4-0,6 \\
3 \\
\end{array}$ & $\begin{array}{c}0,6-0,8 \\
4 \\
\end{array}$ & $\begin{array}{c}0,8-1 \\
5\end{array}$ \\
\hline
\end{tabular}

Sumber: Dall'Osso et al. (2009) dengan Modifikasi

Tabel 2. Nilai Kerentanan Bangunan

\begin{tabular}{|c|c|c|c|c|c|c|c|}
\hline \multirow{2}{*}{ Faktor } & \multicolumn{7}{|c|}{ Nilai } \\
\hline & -1 & $-0,5$ & 0 & 0,25 & 0,5 & 0,75 & 1 \\
\hline $\mathrm{s}$ & $>5$ lantai & 4 lantai & 3 lantai & & 2 lantai & & 1 lantai \\
\hline $\mathrm{m}$ & Beton betulang & & Bata ganda & Bata satu & & & Kayu \\
\hline g & $\begin{array}{l}\text { Open plan } \\
\text { (OP) }\end{array}$ & $\begin{array}{l}\text { OP dan } \\
\text { jendela }\end{array}$ & $50 \% \mathrm{OP}$ & & $\begin{array}{l}\text { Banyak } \\
\text { jendela }\end{array}$ & $\begin{array}{l}\text { Sedikit } \\
\text { Jendela }\end{array}$ & Bukan OP \\
\hline $\mathrm{f}$ & Dalam & & Sedang & & & & Dangkal \\
\hline so & Baik & & Sedang & & & & Buruk \\
\hline mo & & & Minimum & Sedikit & Sedang & Banyak & Ekstrim \\
\hline $\mathrm{pc}$ & Sangat buruk & Buruk & Sedang & & Baik & & $\begin{array}{l}\text { Sangat } \\
\text { baik }\end{array}$ \\
\hline
\end{tabular}


Tabel 3. Nilai Proteksi Bangunan

\begin{tabular}{|c|c|c|c|c|c|}
\hline Faktor & 0 & 0,25 & $\begin{array}{l}\text { Nilai } \\
0,5\end{array}$ & 0,75 & 1 \\
\hline Prot_br & $>10$ & $7-10$ & $4-6$ & $2-3$ & 1 \\
\hline Prot_nb & Sangat tinggi & Tinggi & Sedang & Rendah & $\begin{array}{c}\text { Tanpa } \\
\text { perlindungan }\end{array}$ \\
\hline Prot_sw & $\begin{array}{l}\text { Vertikal, } \\
>5 \mathrm{~m}\end{array}$ & $\begin{array}{l}\text { Vertikal, } \\
3-5 \mathrm{~m}\end{array}$ & $\begin{array}{l}\text { Vertikal, } \\
1,5-3 \mathrm{~m}\end{array}$ & $\begin{array}{l}\text { Vertikal, } 0-1,5 \mathrm{~m} \\
\text { atau } \\
\text { miring, } 1,5-3 \mathrm{~m}\end{array}$ & $\begin{array}{l}\text { Miring, } 0-1,5 \\
\mathrm{~m} \text { atau tidak ada }\end{array}$ \\
\hline Prot_w & $\begin{array}{l}80-100 \% \\
\text { kedalaman } \\
\text { gelombang }\end{array}$ & $\begin{array}{c}60-80 \% \\
\text { kedalaman } \\
\text { gelombang }\end{array}$ & $\begin{array}{c}40-60 \% \\
\text { kedalaman } \\
\text { gelombang }\end{array}$ & $\begin{array}{c}20-40 \% \\
\text { kedalaman } \\
\text { gelombang }\end{array}$ & $\begin{array}{c}0-20 \% \\
\text { kedalaman } \\
\text { gelombang }\end{array}$ \\
\hline
\end{tabular}

\section{c. Eksposur}

Eksposur (Ex) berkaitan dengan kedalaman genangan pada titik di mana bangunan berada. Tingkat kerusakan struktural idealnya meningkat seiring kedalaman air, karena tekanan dan kecepatan aliran merupakan fungsi langsung dari kedalaman aliran (Dall'Osso et al., 2009)

Komponen kerentanan kedua dalam model PTVA-3 adalah kerentanan bangunan karena adanya kontak bangunan dengan air (WV). Ketika lantai suatu bangunan tergenang oleh air akibat tsunami, tentunya seluruh bagian di dalamnya akan memerlukan perbaikan. Dengan demikian, kerentanan bangunan untuk dalam hubungannya dengan kontak air jelas bergantung pada jumlah lantai yang tergenang di setiap bangunan (termasuk ruang bawah tanah).

\section{Metode Analisis Peta Risiko Bangunan}

Risiko bangunan dinyatakan secara kuantitatif dengan menggunakan persamaan berikut:

Risiko $=V^{*} \mathbf{A}$

keterangan:

V ialah kerentanan fisik, ditetapkan sebagai derajad kerusakan dari elemen yang berisiko, dan A ialah kuantifikasi dari bangunan

Nilai kerentanan fisik banguan (V) dalam hal ini diperoleh dari model PTVA-3, sementara itu nilai kuantifikasi bangunan (A) dalam hal ini adalah harga individual bangunan. Untuk mendapatkan harga individual bangunan digunakan pendekatan harga bangunan rerata per $\mathrm{m}^{2}$, sehingga masing-masing bangunan dapat diketahui nilainya dengan mengalikan luas bangunan dengan harga per $\mathrm{m}^{2}$ tersebut. Perolehan informasi harga bangunan dilakukan dengan kegiatan survei lapangan berdasarkan standar harga pada Pajak Bumi dan Bangunan (PBB).

Data harga bangunan per $\mathrm{m}^{2}$ diperoleh dengan cara survei lapangan pada berbagai jenis bangunan yang terdapat di lokasi penelitian. Dalam survei lapangan disusun nilai rerata harga bangunan untuk jenis penggunaan bangunan yang berbeda, kemudian dikalikan dengan luas bangunan, sehingga diperoleh harga individual bangunan.

\section{HASIL DAN PEMBAHASAN}

Hasil digitasi data tapak bangunan dari citra penginderaan jauh memiliki informasi yang sangat terbatas terkait parameter kerentanan bangunan. Atap bangunan yang dapat dikenali dari citra Quickbird digunakan sebagai dasar pengelompokan bangunan. Penentuan kelompok atap bangunan pun didahului dengan survei lapangan yang bertujuan untuk melihat secara sekilas variasi bentuk atap yang terdapat di Kelurahan Ploso. Informasi dari survei pendahuluan ini kemudian dikombinasikan dengan kenampakan di citra Quickbird dan studi literatur (Ronald, 1997), sehingga didapatkan 8 kelompok bentuk atap, yaitu atap kampung, limasan, kampung modifikasi, limasan modifikasi, masjid, joglo dan limasan patah, kompleks dan modern, dan perumahan. Pengelompokan bangunan berdasarkan bentuk atap lebih ditujukan untuk mempermudah teknis pengambilan sampel di lapangan dan mudah dikenali dari citra satelit resolusi tinggi.

Kebanyakan bangunan di Kelurahan Ploso memiliki tipe atap kampung dan limasan, bahkan jumlah keduanya mencapai $73 \%$ dari keseluruhan bangunan. Pada kedua tipe atap tersebut jenis penggunaan bangunan yang sering dijumpai yaitu sebagai permukiman. Sementara itu, untuk tipe atap kampung modifikasi dan limasan modifikasi memiliki jenis penggunaan bangunan berupa kantor pemerintahan, sekolah, dan permukiman. Bentuk atap modifikasi yang ditemui antara lain berbentuk seperti huruf U, L, dan T.

Dalam model bahaya 7,5 Mw sebagian besar bangunan (1.282) masuk ke dalam kelas RVI sangat rendah, dan sebanyak 609 bangunan tersebut memiliki bentuk atap kampung. Bangunan sisanya tergabung dalam kelas RVI rendah dan sedang, masing-masing sebanyak 289 dan 84, namun tidak terdapat bangunan yang termasuk ke dalam kelas tinggi maupun sangat tinggi. Ketiadaan bangunan yang masuk ke dalam 
kelas RVI tinggi dan sangat tinggi ini disebabkan oleh pengaruh nilai kerentanan SV, yang pada model bahaya tsunami 7,5 Mw sebagian besar bangunan termasuk ke dalam kelas kerentanan SV sangat rendah.

Hasil yang berbeda ditemui untuk kerentanan bangunan pada model bahaya $8 \mathrm{Mw}$, yang mana sebagian besar bangunan (1.245) termasuk ke dalam kelas RVI rendah. Akan tetapi masih belum ditemui bangunan yang termasuk ke dalam kelas RVI tinggi ataupun sangat tinggi. Jika dibandingkan dengan model bahaya tsunami 7,5 $\mathrm{Mw}$ terdapat penurunan jumlah bangunan pada kelas RVI sangat rendah dan penambahan jumlah bangunan pada kelas RVI rendah. Hal tersebut terjadi pada semua bentuk atap bangunan. Penambahan jumlah bangunan juga ditemukan pada kelas RVI sedang, namun hanya terjadi pada tiga kelompok bentuk atap bangunan, yaitu atap kampung, atap limasan dan atap kampung modifikasi. Perhitungan RVI pada model bahaya tsunami 8,5 Mw menghasilkan distribusi yang lebih merata, dimana terdapat pula bangunan yang memiliki kelas RVI tinggi dan sangat tinggi. Konsentrasi bangunan pun bergeser menjadi kelas RVI sedang, dengan jumlah bangunan mencapai 1.046. Kelas RVI tinggi dimiliki oleh 155 bangunan, sedangkan kelas RVI sangat tinggi dimiliki oleh 87 bangunan

Pengamatan pada saat survei pendahuluan mengindikasikan bahwa kerentanan bangunan lebih terkait dengan kemampuan ekonomi pemilik bangunan tersebut. Dalam hal ini diasumsikan bahwa semakin tinggi kemampuan ekonominya, maka semakin rendah tingkat kerentanan bangunannya. Dengan kekuatan ekonomi yang berlebih tentunya pemilik leluasa dalam memilih bahan bangunan terbaik dan dibangun pada lahan yang terlindung, atau rekayasa lain yang dapat mengurangi kerentanan bangunan. Bahkan untuk kelompok bangunan yang sama, tetapi jika kemampuan ekonomi pemiliknya berbeda maka berbeda pula tingkat kerentanannya.

Pendekatan harga bangunan dilakukan dengan cara mengalikan luas bangunan dengan harga bangunan per $\mathrm{m}^{2}$. Pada dasarnya harga bangunan memiliki hubungan yang berbanding lurus dengan luasan, dimana semakin luas bangunannya semakin mahal pula harganya. Bangunan paling mahal yaitu bangunan SMA Negeri 1 Pacitan yang memiliki luas 1743,04 m². Secara visual dapat diketahui bahwa Lingkungan Ngampel (RW VII) yang memiliki bangunan-bangunan sekolah yang cukup luas.

Tabel 4 menyajikan data harga bangunan menurut jenis penggunaannya. Pada tabel tersebut pun didapati bahwa sekolah memiliki nilai rerata harga bangunan tertinggi, yaitu Rp 199,4 Juta, sedangkan rerata harga bangunan terendah adalah

Rp 23,4 Juta yang dimiliki oleh rumah dengan kondisi pemeliharaan buruk. Namun demikian secara individual bangunan paling murah merupakan rumah dengan kondisi pemeliharaan sedang, dengan harga Rp 5,3 Juta. Jumlah total harga bangunan di Kelurahan Ploso sendiri hampirmencapai angka Rp 73,6 Miliar. Harga tersebut tentunya masih berada pada standar $\mathrm{PBB}$, jika dikonversi menjadi harga sebenarnya total harga tersebut diperkirakan mencapai Rp 368 Miliar. Persebaran harga bangunan dapat dilihat pada Gambar 3.

Berdasarkan tiga model peta bahaya yang digunakan, model bahaya tsunami 8,5 Mw menyebabkan risiko tertinggi (Tabel 5). Total risiko kerugian bangunan pada model bahaya tsunami 8,5 Mw sendiri bernilai Rp 33,88 Miliar, dua kali lipat dari jumlah risiko pada model bahaya tsunami $8 \mathrm{Mw}$. Rumah dengan kondisi pemeliharaan baik memiliki jumlah risiko kerugian bangunan tertinggi diantara jenis penggunaan bangunan lainnya, dengan nilai risiko mencapai Rp 16,07 Miliar, sedangkan bangunan pabrik tidak berisiko terhadap bahaya tsunami sama sekali karena tidak terpengaruh oleh model tsunami. Nilai rata-rata kerugian bangunan tertinggi, dimiliki oleh bangunan sekolah dan kantor pemerintahan dengan nilai mencapai Rp 0,06 Miliar.

Sebaran risiko bangunan menurut lingkungan (RW) di Kelurahan Ploso dapat dilihat pada Tabel 6. Pengelompokan nilai risiko berdasarkan unit administrasi ini dilakukan karena akan memudahkan manajemen bencana yang dapat disesuaikan dengan urutan birokrasi.

Jumlah risiko tertinggi berada di Lingkungan Barehan dengan jumlah nilai kerugian mencapai Rp 7,8 Miliar. Hal tersebut sangat wajar karena Lingkungan Barehan berbatasan langsung dengan pantai dan konsentrasi permukiman penduduk hanya berjarak 600 $m$ dari garis pantai. Di lain pihak Lingkungan Krajan Kidul memiliki jumlah risiko paling rendah, dengan nilai sebesar Rp 1,7 Miliar. Nilai risiko yang paling rendah tersebut disebabkan karena jumlah bangunan di Lingkungan Krajan Kidul yang memang paling sedikit diantara semua lingkungan.

Nilai risiko maksimum pada data individual tertinggi berada di Lingkungan Kebon, dengan nilai risiko kerugian sebesar Rp 0,3 Miliar. Ketika dilakukan cek silang pada peta, nilai risiko maksimum tertinggi tersebut merupakan bangunan sekolah. Urutan jumlah risiko kerugian bangunan pada tiap lingkungan tersebut dapat dijadikan salah satu pertimbangan dalam pelaksanaan program pengurangan risiko bencana, dimana risiko yang tinggi idealnya mendapat prioritas lebih tinggi. Persebaran risiko kerugian bangunan pada model bahaya tsunami 8,5 Mw dapat dilihat pada Gambar 4. Bangunan-bangunan publik seperti sekolah, pasar, masjid atau kantor pemerintahanbiasanya digunakan untuk lokasi evakuasi pada saat kejadian bencana. 
Tabel 4. Daftar Harga Bangunan Berdasarkan Jenis Penggunaan Bangunan

\begin{tabular}{|c|c|c|c|c|c|c|}
\hline \multirow{2}{*}{ No } & \multirow{2}{*}{$\begin{array}{c}\text { Penggunaan } \\
\text { Bangunan }\end{array}$} & \multirow{2}{*}{ Jumlah } & \multicolumn{4}{|c|}{ Harga Bangunan (dalam juta Rupiah) } \\
\hline & & & Minimum & Maksimum & Rata-rata & Jumlah Harga \\
\hline 1. & Gudang & 8 & 28,5 & 225,8 & 88,4 & 707,5 \\
\hline 2. & Kantor Pemerintahan & 15 & 49,6 & 322,2 & 139,4 & $2.090,8$ \\
\hline 3. & Masjid / Musholla & 18 & 29,8 & 287,8 & 74,1 & $1.334,6$ \\
\hline 4. & SPBU & 1 & 100,9 & 100,9 & 100,9 & 100,9 \\
\hline 5 . & Pabrik & 1 & 190,5 & 190,5 & 190,5 & 190,5 \\
\hline 6. & Rumah-Buruk & 54 & 8,8 & 61,1 & 23,4 & $1.266,3$ \\
\hline 7. & Rumah-Sedang & 683 & 5,3 & 157,7 & 29,0 & $19.797,0$ \\
\hline 8. & Rumah-Baik & 761 & 8,3 & 155,4 & 43,9 & $33.424,5$ \\
\hline 9. & Rumah-Sangat Baik & 66 & 30,6 & 248,5 & 76,9 & $5.075,5$ \\
\hline 10. & Sekolah & 48 & 12,7 & 829,7 & 199,4 & $9.572,7$ \\
\hline \multicolumn{6}{|c|}{ Jumlah total harga bangunan di kelurahan Ploso } & $73.560,3$ \\
\hline
\end{tabular}

Sumber; Hasil Analisis Data

Tabel 5. Nilai Risiko Kuantitatif pada Setiap Lingkungan

\begin{tabular}{lrrrrrrrrrrrrrr}
\hline \multicolumn{1}{c}{$\begin{array}{c}\text { Penggunaan } \\
\text { Bangunan }\end{array}$} & \multicolumn{1}{c}{ Minimum } & \multicolumn{1}{c}{ Maksimum } & \multicolumn{3}{c}{ Rata-rata } & \multicolumn{3}{c}{ Jumlah RisikoBangunan } \\
\hline Gudang & 0 & 0 & 0,01 & 0,02 & 0,02 & 0,06 & 0,01 & 0,01 & 0,04 & 0,06 & 0,06 & 0,32 \\
Kantor Pemerintahan & 0 & 0 & 0,01 & 0,03 & 0,08 & 0,16 & 0,01 & 0,03 & 0,06 & 0,03 & 0,51 & 0,92 \\
Masjid/Musholla & 0 & 0 & 0,01 & 0,07 & 0,07 & 0,14 & 0,01 & 0,07 & 0,04 & 0,11 & 0,27 & 0,65 \\
POM Bensin & 0 & 0,03 & 0,03 & 0 & 0,03 & 0,03 & 0 & 0,03 & 3 & 0 & 3 & 0,03 \\
Pabrik & 0 & 0 & 0 & 0 & 0 & 0 & 0 & 0 & 0 & 0 & 0 & 0 \\
Rumah Buruk & 0 & 0 & 0 & 0,02 & 0,02 & 0,03 & 0 & 0,01 & 0,01 & 0,04 & 0,29 & 0,61 \\
Rumah Sedang & 0 & 0 & 0 & 0,04 & 0,04 & 0,09 & 0 & 0,01 & 0,01 & 1,44 & 4,43 & 9,66 \\
Rumah Baik & 0 & 0 & 0 & 0,06 & 0,06 & 0,11 & 0 & 0,01 & 0,02 & 2,24 & 7,37 & 16,07 \\
Rumah Sangat Baik & 0 & 0 & 0 & 0,07 & 0,07 & 0,13 & 0,01 & 0,02 & 0,04 & 0,72 & 1,30 & 2,63 \\
Sekolah & 0 & 0 & 0 & 0,12 & 0,21 & 0,30 & 0 & 0,02 & 0,06 & 0,23 & 1,03 & 3,01 \\
Jumlah Total & & & & & & & & & & 4,93 & 15,27 & 33,88 \\
\hline
\end{tabular}

Keterangan: = Model bahaya $7,5 \mathrm{Mw} ; \quad=$ Model bahaya $8 \mathrm{Mw}$; = Model bahaya $8,5 \mathrm{Mw}$

Tabel 6. Nilai Risiko Kuantitatif pada Setiap Lingkungan

\begin{tabular}{clccccr}
\hline \multirow{2}{*}{ RW } & Lingkungan & Jumlah & \multicolumn{3}{c}{ Risiko Kerugian Bangunan (dalam juta Rupiah) } \\
& Bangunan & Minimum & Maksimum & Rata-rata & Jumlah Risiko \\
\hline 1 & Blumbang & 130 & 0 & 78,83 & 20,23 & $2.629,63$ \\
2 & Temon & 252 & 0 & 152,04 & 16,70 & $4.207,79$ \\
3 & Kebon & 261 & 0 & 295,70 & 19,40 & $5.064,58$ \\
4 & Krajan Lor & 144 & 3,25 & 72,44 & 18,29 & $2.634,24$ \\
5 & Krajan Kidul & 97 & 2,35 & 54,11 & 17,30 & $1.677,96$ \\
6 & Peden & 119 & 0 & 143,88 & 16,10 & $1.916,01$ \\
7 & Ngampel & 406 & 0 & 205,79 & 19,37 & $7.865,21$ \\
8 & Barehan & 246 & 6,18 & 111,95 & 32,03 & $7.880,52$ \\
Jumlah & Total & & & & $33.875,95$ \\
\hline
\end{tabular}

Sumber: Hasil Analisis Data 


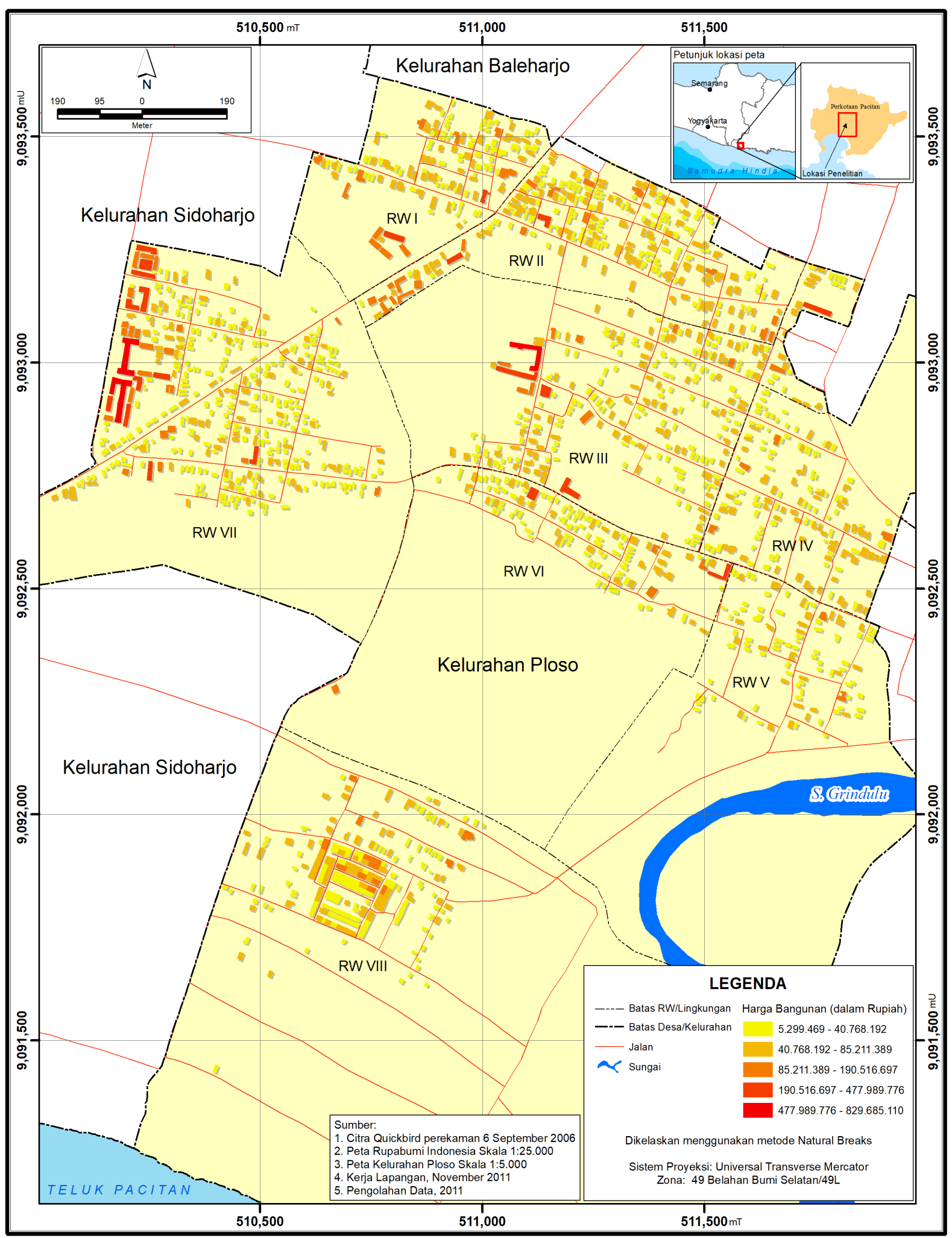

Gambar 3. Persebaran Harga Bangunan di Kelurahan Ploso, Kabupaten Pacitan 


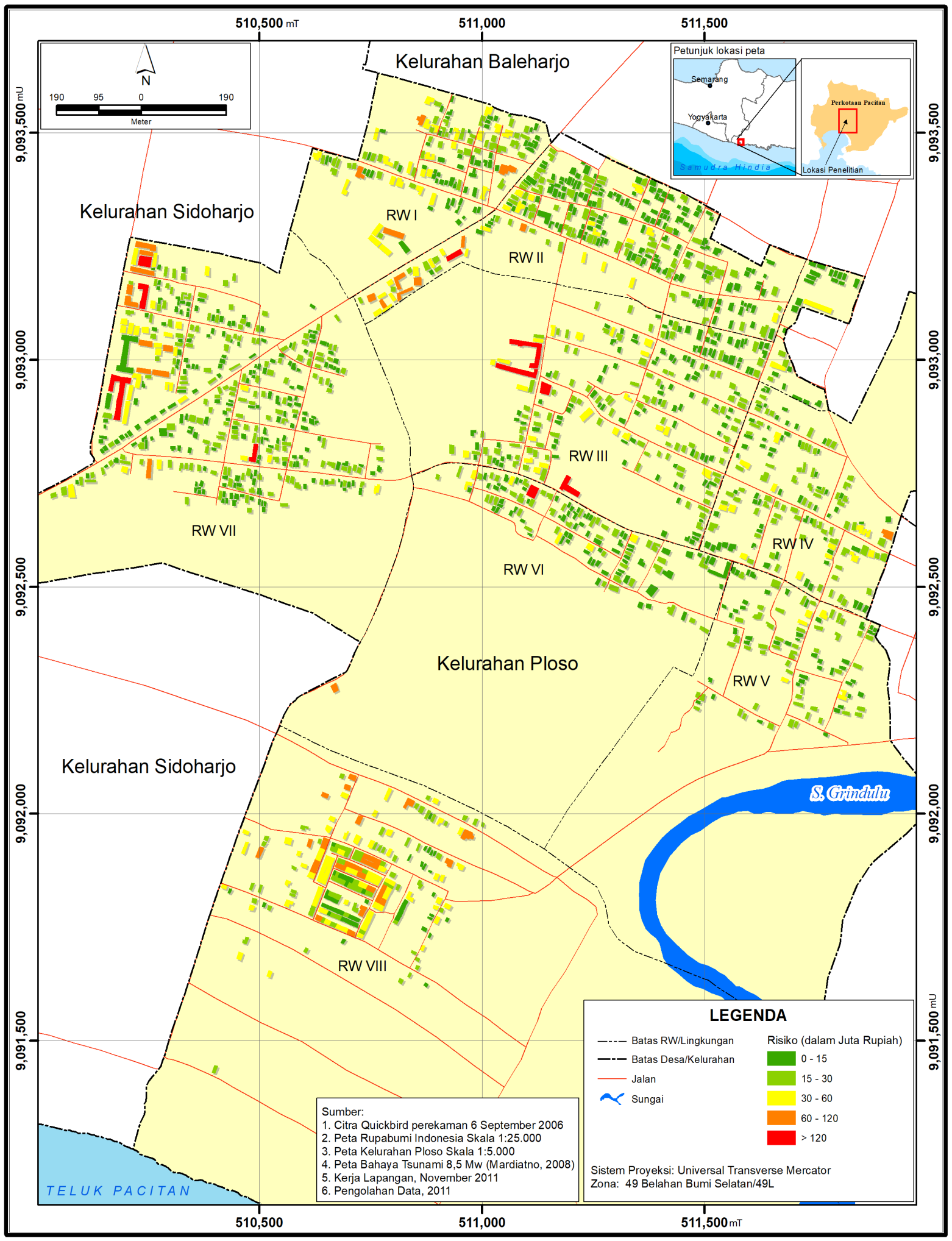

Gambar 4. Peta Risiko Tsunami Terhadap Bangunan pada Model Bahaya 8,5 Mw 
Berdasarkan hasil pada Gambar 4 diketahui bahwa tidak sedikit dari bangunan yang dapat digunakan untuk evakuasi tersebut yang memiliki risiko tinggi, bahkan untuk bangunan yang terletak cukup jauh dari garis pantai. Temuan ini tentunya sangat bermafaat sebagai bahan pertimbangan untuk penentuan lokasi evakuasi. Selain itu, temuan ini juga akan sangat membantu dalam tahapan managemen bencana yang lebih baik di masa mendatang.

\section{KESIMPULAN}

Secara umum pada model bahaya tsunami 8,5 Mw, bangunan di Kelurahan Ploso memiliki kerentanan sedang, sehingga diperlukan upaya untuk mengurangi kerentanan bangunan. Diantara semua lingkungan di Kelurahan Ploso, Lingkungan Barehan (RW VIII) merupakan daerah yang memiliki kerentanan bangunan sangat tinggi. Jika dilihat dari komponen kerentanan, letak bangunan (dekat pantai), jumlah lantai (satu), dan arah hadap dinding utama (tegak lurus terhadap arah tsunami), merupakan komponen yang paling mempengaruhi tingginya kerentanan bangunan di Lingkungan Barehan.

Sementara itu, jika dilihat kerentanan secara keseluruhan kondisi pemeliharaan bangunan adalah komponen kerentanan yang berpengaruh pada kerentanan bangunan di Kelurahan Ploso. Pemeliharaan bangunan erat kaitannya dengan kemampuan ekonomi pemilik rumah. Semakin tinggi kemampuan ekonomi, maka semakin baik pula tingkat pemeliharaan bangunannya. Bahkan mampu meningkatkan faktor proteksi dengan cara menanam hambatan alamiah atau membangun tembok di sekeliling bangunan. Sayangnya tingkat pemeliharaan bangunan tersebut berbanding terbalik dengan kerentanan bangunan.

Kondisi kerentanan bangunan di Kelurahan Ploso tersebut berbanding lurus dengan potensi risiko kerugian bangunannya. Diantara jenis penggunaan bangunan lainnya, bangunan rumah/permukiman penduduk memiliki potensi kerugian tertinggi, terlebih yang berlokasi di Lingkungan Barehan.

\section{DAFTAR PUSTAKA}

BPS. (2011). Kecamatan Pacitan dalam Angka 2010. Pacitan: BPS Kabupaten Pacitan, Jawa Timur.

Dall'Osso, F., Gonella, M., Gabbianelli, G., Withycombe, G. \& Dominey-Howes, D. (2009). A Revised (PTVA) Model for Assessing the Vulnerability of Buildings to Tsunami Damage. Natural Hazards Earth System Science, 9, 1557-1565.

Latief, H., Puspito, N., \& Imamura, F., (2000), Tsunami Catalog and Zones in Indonesia. Journal of Natural Disaster Science, 22(1), 25-43.
Mardiatno, D. (2008). Tsunami Risk Assessment Using Scenario-Based Approach, Geomorphological Analysis and Geographic Information System: A Case Study in South Coastal Areas of Java IslandIndonesia. Disertasi. Innsbruck: Austria: Faculty of Geo-and Atmospheric Sciences. University of Innsbruck.

Mardiatno, D. (2013). A Proposal for Tsunami Mitigation by Using Coastal Vegetation: Some Findings from Southern Coastal Area of Central Java, Indonesia. Journal of Natural Resources and Development, 3, 85-95.

Marfai, M.A., King, L., Singh, L.P., Mardiatno, D., Sartohadi, J., Hadmoko, D.S. \& Dewi, A. (2008). Natural hazards in Central Java Province, Indonesia: an Overview, Environmental Geology, $56,335-351$.

National Geophysical Data Center/ World Data Center (NGDC/WDC). (2011). Historical Tsunami Database, Boulder, CO, USA. dapat diakses di http://www.ngdc.noaa.gov/hazard/tsu db.shtml

Okal, E.A. \& Synolakis, C.E. (2008). Far-field Tsunami Hazard from Mega-Thrust Earthquakes in the Indian Ocean, Geophysics Journal Int., 172(3), 995-1015.

Ramroth, W.G. (2007). Planning for Disasters: How Natural and Man-Made Disasters Shape The Built Environment. New York: Kaplan Publishing.

Reese, S., Cousins, W.J., Power, W.L., Palmer, N.G., Tejakusuma, I.G. \& Nugrahadi, S. (2007). Tsunami Vulnerability of Buildings and People in South Java - Field Observations After the July 2006 Java tsunami. Natural Hazards Earth System Science, 7, 573-589.

Ronald, A. (1997). Ciri-ciri Karya Budaya di Balik Tabir Keagungan Rumah Jawa. Yogyakarta: Penerbitan Universitas Atma Jaya Yogyakarta.

Sunarto \& Rahayu, L. (2006). Model Prevensi Gempabumi dan Tsunami pada Lowland di Wilayah Teluk Pacitan. Yogyakarta: Pusat Studi Bencana Universitas Gadjah Mada.

Smith, K. \& Petley, D.N. (2008). Environmental Hazards: Assessing Risk and Reducing Disaster (5th Edition). New York: Routledge.

UNDP. (2004). Reducing Disaster Risk: A Challenge for Development. New York: John S. Swift Co.

Warnitchai, P. (2005). The 26 December 2004 Tsunami Disaster in Thailand: Experience and Lesson Learned. Proceedings of the 4th International Symposium on New Technologies for Urban Safety of Mega Cities in Asia. Singapore, 18-19 October, 2005. 
Westen, C., Kingma, N., \& Montoya, L., (2009). Multi Hazard Risk Assessment, Educational Guide Book Session 4: Elements at Risk, diedit oleh Cees van Westen. Enschede, The Netherlands: ITC.

Widianto, A. \& Damen, M. (2014). Determination of Coastal Belt in the Disaster Prone Area: A Case Study in the Coastal Area of Bantul Regency, Yogyakarta, Indonesia, Indonesian Journal of Geography, 46(2), 125-137. 